\title{
OF MAD DOGS AND SCIENTISTS: THE PERILS OF THE "CRIMINAL-INSANE"
}

\author{
ROBERT A. BURT $\dagger$
}

Chief Judge David L. Bazelon has stood at the meeting point of psychiatry and the criminal law during the past twentyfive years. The hopes and happy promises, the disappointments and recriminations of that uneasy conjunction are vividly refracted in his judicial career. Durham ${ }^{1}$ is the first large landmark. The explicit intent of that opinion was to permit psychiatrists to explain antisocial conduct in the language of their discipline, unencumbered by competing conceptual constructs drawn, for example, from quasi-religious explanations of "bad behavior." But there was a larger purpose behind this strategy. Durham solicited psychodynamic explanations of criminal conduct because these seemed to offer hopeful directions for a more constructive, humane social response to criminal deviancy. Psychiatrists would offer not only their explanations but, more importantly, their prescriptions for cure in the dramatic liturgy of the criminal trial. The public would be seized by these performances and persuaded to commit the resources needed to meet these prescriptions.

The script has not gone that way. For a time, Judge Bazelon's opinions seemed to blame the actors in the drama-the trial courts, attorneys, and most pointedly the psychiatric witnesses-for failing to understand and to communicate intelligibly the best psychodynamic theories about antisocial conduct. ${ }^{2}$ But the true villain of the piece appears center stage twelve years after Durham in the "right to treatment" case, Rouse $v$.

$\dagger$ Professor of Law and Professor of Law in Psychiatry, University of Michigan. A.B. 1960, Princeton University; M.A. 1962, Oxford University; J.D. 1964, Yale University. Law Clerk to Chief Judge Bazelon, 1964-65.

Copyright $1974{ }^{\circ}$ by Robert A. Burt.

1 Durham v. United States, 214 F.2d 862 (D.C. Cir. 1954).

${ }^{2}$ See United States v. Brawner, 471 F.2d 969, 1010 (D.C. Cir. 1972) (Bazelon, C.J., concurring in part and dissenting in part); Washington v. United States, 390 F.2d 444 (D.C. Cir. 1967); Rollerson v. United States, 343 F.2d 269 (D.C. Cir. 1964). 
Cameron. ${ }^{3}$ Charles Rouse had been found not guilty of a criminal offense by reason of insanity, under the Durham formulation, and confined in a public mental institution for several years. Where, Judge Bazelon asked, was even the semblance of treatment resources for Rouse that the psychiatrists had appeared to promise?

This year, twenty years after Durham, in a significant lecture at the annual meeting of the American Psychiatric Association, Judge Bazelon concluded that the "Durham experiment" had been a "failure." 4 This is an accurate appraisal only in one sense: the initial hopes that psychiatric insights would lead to fundamental improvements in the criminal justice system have not been realized. But in another sense Durham has not failed. An experiment succeeds not only by proving the experimenter's initial hypothesis. The Durham experiment has succeeded by graphically demonstrating a proposition of considerable social importance: the conjoining of psychiatry and the criminal law frequently (perhaps inevitably) produces mutual misunderstandings and defeats optimistic expectations on all sides.

This lesson is critically important for evaluating current claims both to promote and to oppose development of new technologies for the control of antisocial conduct. Current popular belief sees frightening, mounting waves of crime and, even worse, crime justified in a new, more terrifying way. From the Attica uprising to terrorist kidnappings by self-styled "liberation armies," violent criminal activity is increasingly depicted as political struggle between warring classes. This politicization of crime, and its concomitant celebration of vengeful domestic violence, is now characteristic of both the forces of "order" and the forces of "disorder," of both the police forces and the anti-police forces.

The stage is thus set for a new drama. On the one side are the technological hucksters, eagerly joined by some political leaders and correctional administrators. In response to the claim that violence is legitimate political protest, it is obviously much more comfortable, much more conscience appeasing, to characterize this violence as merely symptomatic of illness or specifically of diseased brains. This is a thesis offered by prominent

3373 F.2d 451 (D.C. Cir. 1966). Cf. A. Goldstein, The Insanity Defense 7 (1967).

"Address by Chief Judge Bazelon, "The Perils of Wizardry," Annual Meeting of the American Psychiatric Association, Detroit, Michigan, May 7, 1974, at 9-12 (typescript) [hereinafter cited as "Wizardry"]. 
proponents of psychosurgery. ${ }^{5}$ From the other side, we can expect fervid denunciations of all science, of all attempts at systematic understanding and amelioration of socially deviant violence. The grandiosity of the technological hucksters, and the transparently unpleasant motives of their main social allies, will give plausibility to this Luddite response.

In his lecture to the American Psychiatric Association, Judge Bazelon spoke of this newly touted behavioral technology:

In the 1930's and 1940's atomic scientists stood on the threshold of unlocking the secrets of the atom, ushering in the nuclear era. Today, the biobehavioral scientist stands on the threshold of unlocking many of the secrets of the brain. ${ }^{6}$

This comparison aptly evokes the question whether we can reap the benefits promised by this new technology without being overwhelmed by the destructive forces it places in our hands.

The Durham experiment offers some guidance. Durham is, first of all, a paradigm of a traditional American response to criminal deviance: the conjunction of the policeman and the medicine man. But more than that, Durham provides a very special meeting ground for these professions-the highly visible, reified social and medical status of "criminal-insane." This status is not restricted in our jurisprudence to the insanity defense alone. Specialized social response to the "criminal-insane" is mandated for criminal defendants found incompetent to stand trial, ${ }^{7}$ for sexual offenders found to be "criminal sexual psychopaths,"8 for offenders found to be "defective delinquents," for persons civilly committed because of "mental illness and dangerousness to others," 10 and for prisoners found "mentally ill" during their criminal sentence terms. ${ }^{11} \mathrm{I}$ believe that these "criminal-insane" statuses provide precisely the worst, most socially harmful model for collaboration between the criminal law and psychiatry (and the behavioral technologies generally). It is the central thesis of this Article that the rigid delineations between persons in these statuses and the general criminal popu-

\footnotetext{
${ }^{5}$ For a critical discussion, see E. Valenstein, Brain Control 248-63 (1973).

6 "Wizardry," supra note 4 , at 1 .

${ }^{7}$ See text accompanying notes 49-67 infra.

${ }^{8}$ See text accompanying notes 87-93 infra.

${ }^{9}$ See id.

${ }^{10}$ See text accompanying notes 69-75 infra.

"See text accompanying notes 94-96 infra.
} 
lation must be abolished to help forestall easy social acceptance of the worst abuses of the new correctional biotechnology, and to help preserve the possibility of sensible future collaboration between behavioral sciences and the criminal law.

\section{Retaining or Abolishing the}

\section{"Criminal-INSANe" Statuses: Whose Burden?}

I have argued elsewhere that novel biotechnologies which patently threaten basic concepts of human dignity, such as psychosurgery or implantation of monitoring electrodes in the brain, should not be used in the correctional setting until they are wholly perfected and widely accepted for use in the free community. ${ }^{12}$ But, whatever the merits of that argument, not all of the new biotechnology is so obviously offensive, and even for such techniques as aversive conditioning (for example, electric shocks psychologically linked to perverse sexual desires) the new technology often becomes quickly faddish and thus apparently no longer "experimental." 13 If there is a need to protect prisoners, and the correctional system, from inappropriate uses of behavioral technology, those protections must reach beyond such clear problems as experimental psychosurgery.

There is such need. Charles Rouse exemplifies one aspect of that need. He came to the attention of the criminal justice system with a misdemeanor charge of carrying a dangerous weapon. The maximum possible prison term on this charge was one year. But Rouse's attorney, inspired by Durham, brought the psychodynamic roots of his client's conduct to the court's attention. ${ }^{14}$ Consequently Rouse spent some five years confined in a public mental institution which he, at least, judged to have given him nothing. Rouse's plight is not unique. The systematic empirical research available in current literature has uniformly found that those persons caught in the "criminal-insane" statuses are as a rule confined for longer terms than comparable persons who are socially labelled either "criminal" or "insane" alone. ${ }^{15}$

${ }^{12}$ Burt, Why Keep Prisoners from the Doctors: Reflections on the Detroit Psychosurgery Trial, 3 Hastings Center Studies, No. 1 (forthcoming).

${ }^{13}$ See, e.g., R. Schwitzgebel, Development and Legal Regulation of Coercive Behavior Modification Techniques with OfFenders 8-15 (National Institute of Mental Health, Public Health Service Pub. No. 2067, 1971).

${ }^{14}$ See Rouse v. Cameron, 387 F.2d 241 (D.C. Cir. 1967).

15 See, e.g., H. Steadman \& J. Cocozza, Careers of The Criminally Insane (publication forthcoming); McGarry, The Fate of Psychotic Offenders Referred for Trial, 127 AM. J. 
This documented experience reflects the common sense of the matter. Both the "criminal" and the "insane" depictions present a frightening visage. The two together must necessarily add terror to each. In the public's view these two are at least the sum of their parts, if not more. But this might not be wrong: if in fact the longer confinements of the "criminal-insane" reflected that they were more dangerous than persons carrying either depiction alone, it would be hard to quarrel with such confinement.

In the available research literature, this proposition cannot be conclusively documented one way or the other. There is, however, good reason to suspect, as a general matter, that the "criminal-insane" population is not much different from the other confined populations and that application of those labels reflects more bad luck than reliably bad prognosis for its recipients. The basis for this suspicion is two-fold. First, the doctrines used to sort out the "criminal-insane"-the insanity defense, "sexual psychopathy," incompetency to stand trial, and the like-both in their conceptual roots and in their practical applications offer only haphazard demarcations against ordinary criminal or mental illness standards. ${ }^{16}$ Second, those researchers who have systematically searched for reliable indicia of future dangerousness among any of these designated populations -criminal, insane, or "criminal-insane"-have found that substantial overprediction was necessary to identify any significant number of persons who would in fact subsequently act dangerously. ${ }^{17}$ This literature does not, of course, establish that there are no further refinements possible among these groups, but the task has not yet been accomplished.

Thus, on the basis of the best current data, we can confidently say only that there is reason to suspect that the "criminalinsane" as a group are no more dangerous than other confined populations. But without clear proof this suspicion is not a sufficient basis for proposing abolition of the "criminal-insane" statuses, because there is also reason to suspect the opposite-

P̈sychiat. 1181 (1971); McGarry \& Bendt, Criminal vs. Civil Commitment of Psychotic Offenders: A Seven-Year Follow-up, 125 Am. J. Psychiat. 1387 (1969). Cf. A. Matrhews, Mental Disability and the Criminal. Law 138 (1970).

${ }^{16}$ See, e.g., S. Brakel \& R. Rock, The Mentally Disabled and the Law 358 (rev. ed. 1971); A. MAtThews, supra note 15, at 85-87; Morris, Psychiatry and the Dangerous Criminal, 41 S. CAL. L. Rev. 514 (1968).

${ }^{17}$ See Morris, supra note 16, at 529-36; Rubin, Prediction of Dangerousness in Mentally Ill Criminals, 27 Arch. Gen. Psychiat. 397 (1972); Wenk, Robison \& Smith, Can Violence be Predicted?, 18 Crime \& Delinquency 393 (1972). 
that the "criminal-insane" are very different indeed from these other groups. The basis for this opposite suspicion is grounded in popular perceptions of the hard core cases in each group. The "criminal": a calculating man who attacks for gain and who, accordingly, can be persuaded by social sanctions that "crime does not pay." The "insane": a senile and eccentric madman blithely remote from our common world who threatens only his own well-being. Finally, the "criminal-insane": a violent madman who cannot rationally be dissuaded from his conduct by application of sanctions, and whose consequent unpredictability is a constant, erratically terrifying threat to our sense of communal order.

Such hard core cases can be found in each of these populations. The central question for social policy is whether the existence of these hard core cases adequately justifies continued institutional adherence to the elaborate trappings of separate categorizations. The answer to this policy question might depend on head counts, determining whether the hard core and thus reliably "different" cases were more or less sufficiently prevalent among these different groups. The absence of conclusive data only poses a further question: should the categorizations continue to exist without conclusive data justifying rejection of or adherence to them? Because of the shortcomings of available data, either retaining or abolishing the "criminal-insane" statuses must depend in large part on an act of faith. Thus to answer this further question we must turn to some species of social theology and ask whether important values are more threatened than advanced by adherence to the "criminal-insane" statuses.

Let me approach this question anecdotally first, drawing from the experience of the Detroit psychosurgery trial last year. ${ }^{18}$ This litigation was initiated in response to an experiment under way at the Lafayette Clinic in Detroit to perform psychosurgery on a group of purportedly dangerous confined persons. Only one subject had been selected when the litigation was filed. That subject, known at trial as John Doe, had been confined in the state maximum security mental institution for eighteen years. In 1955, he had allegedly confessed to a brutal rape-murder and, as an alternative to criminal trial, he was found by the court to be a "criminal sexual psychopath" under

${ }^{18}$ Kaimowitz v. Department of Mental Health, 2 Prison L. REP. 433 (Mich. Cir. Ct., Wayne County, 1973). 
the specially designated Michigan statute. ${ }^{19}$ In the course of the psychosurgery trial, considerable doubts were raised about whether John Doe was reliably different, even by any generally applied psychiatric diagnostic criteria, from a broad range of alleged or convicted murderers in the ordinary prison population. ${ }^{20}$ These doubts pointed to another question: how did it happen that John Doe, in particular, was chosen as a potential experimental subject from all of the apparently dangerous people in Michigan institutions? The answer to this question was clear from the initial research protocol. The experimenter intended to perform psychosurgery only on persons who were confined as "criminal sexual psychopaths." However much these few persons might overlap in psychological and social characteristics with others in Michigan institutions, the "criminal sexual psychopath" label singularly attracted the experimenter's attention.

John Doe testified during the psychosurgery trial. In exploring how he was selected for the experiment, Doe was asked to describe his "feelings about" the conditions of his confinement. He responded:

Well, overall, it is not a very good attitude. I must truthfully say that. The hospital was set up for detention, and as far as I am concerned, the attitude and the policies toward patients when I first went there were very nil. I have the feeling that when I was put there that it was just nothing but for detention and to get rid of me and, well, a place to stay. And this is the way it has been over the years. Of course, I have never been mistreated really physically, but the emotional treatment has been like-as far as I am concerned-it has been like a dog in a pen. And that is about it. ${ }^{21}$

John Doe's view that he had been treated "like a dog in a pen" is not uniquely ascribable to his status as a "criminal sexual psychopath." This society in significant ways treats all prisoners, confined under whatever rubric, as "animals." We keep them in

${ }^{19}$ No. 165, [1939] Mich. Acts 323 (repealed 1968). Continued detention for those previously held as criminal sexual psychopaths under the repealed statute was authorized by Mich. Comp. Laws ANN. \$ 330.35(b) (Supp. 1974).

${ }^{20}$ See testimony of Dr. Andrew S. Watson, Trial Transcript, Apr. 4, 1973, passim, Kaimowitz v. Department of Mental Health, 2 Prison L. ReP. 433 (Mich. Cir. Ct., Wayne County, 1973).

21 Testimony of John Doe, id. 5. 
cages, after all. But there is a special social danger that comes from confinement of persons in highly visible, medical-sounding "criminal-insane" statuses. This danger can be seen between the lines of a statement by B. F. Skinner, one of the most prominent apostles of novel uses of biotechnology for social control. Skinner has responded to the charge that the new biotechnology treats "the man who survives as a mere animal" in this way:

"Animal" [he says] is a pejorative term, but only because "man" has been made spuriously honorific. [Some people have] argued that whereas the traditional view supports Hamlet's exclamation, "How like a god!," Pavlov, the behavioral scientist, emphasized "How like a dog!" But that was a step forward. A god is the archetypal pattern of an explanatory fiction, of a miracle-working mind, of the metaphysical. Man is much more than a $\mathrm{dog}$, but like a dog he is within range of a scientific analysis. ${ }^{22}$

This cool view of man fits comfortably within well-accepted, socially beneficial scientific traditions. The proposition that man for some purposes may be viewed as an animal, like any other, or as a mechanistic assemblage of working organs, is the central tenet of biological understanding and therapies for the diseases of man. Unless we are able to conceptualize man as something other than unique and inviolable, unless we are able to see him as also an ordinary animal or a machine it is impossible to think that a surgeon could ever comfortably plunge a knife into the supine restrained body facing him from the operating table. But even in ordinary medical practice, considerable tension is generated by the technological imperative that "dehumanizes" in some degree, however fleetingly, however denied, human beings who are patients. Daniel Callahan has aptly identified this "dilemma, which is at once psychological, ethical and sociological . ..":

How can we manage both to live humanely with ... disease and yet to conquer it at the same time? Both goals seem imperative and yet the logic of each is different. We cure disease by ceasing to romanticize it, by gathering our powers to attack it, by making it an enemy to be conquered. We learn to live with a disease, however, in a very different way: by trying to accept

${ }^{22}$ B.F. SKINNER, BEYONd FREEdoM AND Dignity 201 (1971). 
and cherish those who manifest it, by shaping social structures and institutions which will soften the individual suffering brought on by the disease, by refusing to make the bearer of the disease our economic, social or political enemy. ${ }^{23}$

As difficult as this dilemma is to manage in ordinary medical practice, its difficulty is staggeringly compounded in scientific pursuits with captive populations. When this society saw John Doe, and when he saw himself, as a "dog in a pen," none of us had in mind Skinner's carefully calibrated scientific view. If we join these different definitions together, ineluctably and uncontrollably they redefine, distort, and magnify one another. When the medicine man and the policeman join forces to devise means for combatting violence, they are together offering to define the violent criminal for us as a wild animal, a "mad dog." When our social institutions give special weight, prior legitimation, and routinized operation to this social and medical view, those institutions weaken the already tenuous constraints that keep us from imposing horrifying inflictions on those we fear and would conquer.

The special danger of the "criminal-insane" statuses is that they give a visible patina of science to a particular group, thus producing candidates for technologies that we otherwise might not dare to practice on anyone. Current fervid social debate about "the true nature" of convicted criminals generally-are they political prisoners, bad men, sick men, or some or all of these?-keeps this population in a more protected status of indeterminacy. But for the labelled, prepackaged groups of the "criminal-insane," technological targeting is that much easier.

Some recent social science experiments provide chilling data on this score. Stanley Milgram, a psychologist at Yale University, designed an ingenious set of experiments to test obedience to authority that commands infliction of considerable pain on others. ${ }^{24}$ Milgram's subjects were drawn from a cross-section of the New Haven and Bridgeport, Connecticut, populations by newspaper advertisements and telephone solicitation, asking that they participate in experiments to test the effect of punishment on learning. Upon arriving at the laboratory, the subjects were

${ }^{23}$ D. Callahan, The Tyranny of Survival 230 (1973).

${ }^{24}$ S. Milgram, Obedience to Authority (1974). 
met by a gray-coated technician and another apparent subject (who was in fact a trained actor). By rigged drawing of lots, the subjects were chosen as "teachers" and the actor chosen as "learner." The "learner" was then strapped in a chair, and the "teacher" was instructed by the experimenter to give memory tests to the learner and to administer electric shocks of increasing severity for each wrong answer. The teacher-subject administered the shocks by depressing different levers on an instrument panel before him; the levers had thirty gradations designated from 15 to 450 volts, and these voltage designations were grouped together under labels ranging from "slight shock" at 15 volts, "extreme intensity shock" at 255 volts, "danger: severe shock" at 375 volts, and at 435 volts only an artful "XXX."25

During the entire sequence, the "learner" was in fact not shocked at all, though the teacher-subject's belief that he was actually administering very painful shocks was reinforced in a number of ways, including the administration to the subject himself of a jarring 75 volt shock from this apparatus at the beginning of the experiment. The "learner-victim" responded to the subject's acts in depressing the shock levers in this way:

[T] he victim indicated no discomfort until the 75-volt shock was administered, at which time there was a little grunt. ... [A]t 120 volts the victim shouted to the experimenter that the shocks were becoming painful. Painful groans were heard on administration of the 135 -volt shock, and at the 150 volts the victim cried out, "Experimenter, get me out of here! I won't be in the experiment any more! I refuse to go on!" Cries of this type continue with generally rising intensity, so that at 180 volts the victim cried out, "I can't stand the pain," and by 270 volts his response to the shock was definitely an agonized scream. Throughout, from 150 volts on, he insisted that he be let out of the experiment. At 300 volts the victim shouted in desperation that he would no longer provide answers to the memory test. ${ }^{26}$

Whenever the teacher-subject turned questioningly to the laboratory technician during this sequence, the experimentertechnician would direct him to continue the memory test and the

${ }^{25} I d .13-31$.

${ }^{26}$ Id. 23. 
escalating electric shocks. The experimenter's direction followed this regular sequence, as described by Milgram:

Prod 1: Please continue, or, Please go on.

Prod 2: The experiment requires that you continue.

Prod 3: It is absolutely essential that you continue.

Prod 4: You have no other choice, you must go on. ${ }^{27}$

If the teacher-subject asked whether the learner-victim was being harmed by the shocks, the experimenter-technician would respond, "Although the shocks may be painful, there is no permanent tissue damage, so please go on. (Followed by Prods 2, 3, and 4 , if necessary.)" 28

The purpose of the experiment was to see whether and when the teacher-subject would refuse to continue administering the shocks. The results were profoundly disturbing. In one variation, with the victim in an adjoining room but clearly audible, twenty-five of forty teacher-subjects $(62.5 \%)$ administered the highest shock levels possible, at the XXX designations, in obedience to the experimenter's direction. With the victim in the same room, sixteen of forty $(40 \%)$ escalated the shocks to the highest limits. With the subject and victim side by side, and the subject required to press the victim's hand onto a metal plate to administer the shock, twelve of forty (30\%) continued through the XXX level. ${ }^{29}$ In another set of variations, the victim mentioned as he was being strapped into the chair that he had "a slight heart condition." When the shock level reached 150 volts, the victim stated that his heart was "starting to bother" him and he repeated this complaint several times with, finally, an "intense and prolonged agonized scream" at 330 volts. ${ }^{30}$ This variation did not change the experimental results at all. Milgram concluded, "Probably there is nothing the victim can say that will uniformly generate disobedience; for the teacher's actions are not controlled by him."31

It is hard to understand fully what did control the teachersubjects' actions. In an obvious sense, of course, the experimenter was in control. But the crucial question is why the

\footnotetext{
${ }^{27} I d .21$.

${ }^{28} \mathrm{Id}$.

${ }^{29}$ Id. 34-35 (Table 2).

${ }^{30}$ Id. 55-57.

${ }^{31}$ Id. 57.
} 
teacher-subjects were willing to yield control of their actions to the experimenter and to engage in recklessly cruel conduct toward another human being. The mystique of Science, which cloaked the experimenter, was likely an important determinant here. In other variations of this experiment, the subject was left alone in the laboratory though the experimenter first told him "he was free to select any shock level on any of the trials." 32 In this variation, twenty-eight of forty "went no higher than the [learner-victim's] first indication of discomfort, and 38 did not go beyond the point where the learner vehemently protested [150 volts]." ${ }^{33}$ In yet another variation, the gray-coated technician was called away from the laboratory (on a ruse) and authorized the experiment to be conducted by an "ordinary man" (another actor who appeared to arrive at the laboratory at the same time as the teacher-subject). In this variation, only four subjects of twenty (20\%) obeyed the "ordinary man's" directives to administer the maximum possible shocks. ${ }^{34}$

The Milgram experiments suggest a central role to the selfjustifying norms of Science in another, ironic way. The conduct of the experiments themselves has been sharply attacked on the ground that Milgram deceived his subjects in multiple ways and led them unwittingly into an experience which, for the obedient subjects, brought them "to live with the realization that they were willing to yield to destructive authority to the point of inflicting extreme pain on a fellow human being."35 Milgram himself discounted this criticism, describing postexperimental measures to avoid adverse impact on the subjects and stating that follow-up studies of his subjects revealed no psychological harm. He suggested, at least by implication, that the absence of adverse impact on the subjects is itself an intriguing finding of the experiment. ${ }^{\mathbf{3 6}}$ Milgram may be correct in these observations, but it is nonetheless clear that he took extraordinary risks with the future emotional well-being of his subjects in these experiments. His vivid depictions of their stress in administering the shocks is itself testimony to this. ${ }^{37}$ It is further clear that if Milgram had simply

${ }^{32} I d .71$.

${ }^{33}$ Id. 72.

${ }^{34}$ Id. 94 (Table 4).

${ }^{35}$ Kelman, Human Use of Human Subjects: The Problem of Deception in Social Psychological Experiments, 67 Psychol. Buld. 1, 5 (1967). See also Experimentation with Human BeINGs 395-406 (J. Katz ed. 1972) [hereinafter cited as J. Katz].

${ }^{36}$ S. Milgram, supra note 24 , at 193-202.

${ }^{37}$ Id. 44-54, 73-88. 
lured people into these practices for his own personal amusement, we would not hesitate to condemn his action as grotesque sadism. The question is made more complex, and Milgram finds professional and personal refuge, through the ethos of Science. The lesson is tautly drawn. That ethos can make victimizers and victims of any of us.

Casting Science as the villain here should not be misconstrued as an attack on the social worth of scientific thought. It is vital, as noted earlier, that the surgeon poised with his knife be able momentarily to "dehumanize" his patient-to see him as a laboratory animal or a machine-so that he can overlook the patient's abject fear and intense pain caused by the process of surgery itself. The surgeon is further assisted by his educated belief that the procedure will benefit the patient in the long run and that the patient wants his momentary fears and pain to be disregarded. But if benevolence may be practiced only when the practitioner suppresses his own instinctual sympathy with the immediate suffering of a fellow human being before him, the psychological preconditions for great and destructive confusions are created. The victimizers in the Milgram experiments fell victim to these confusions. The commands of Science took life on their own.

The same dynamic occasionally becomes starkly visible from within correctional institutions. Consider the experiment which was carried out in 1967 and 1968 at the California correctional institution at Vacaville. ${ }^{38}$ (The State Department of Corrections calls this institution the California Medical Facility, and describes it as a "psychiatric treatment facility" 39 for convicted offenders.) Sixty-four inmates at Vacaville were identified as highly disruptive or so-called "extreme acting-out" individuals. Of these, some were made experimental subjects and those remaining were made the control group. Some of the experimental subjects agreed to participate but some were included involuntarily. ${ }^{40}$ Whenever one of the experimental subjects violated an institu-

${ }^{38}$ This experiment is described in Mattocks \& Jew, Assessment of an Aversive "Contract" Program with Extreme Acting-Out Criminal Offenders, in J. Katz, supra note 35, at 1016 [hereinafter cited as Assessment].

39 This depiction appears in A. Mattocks \& C. Jew, Assessment of an Aversive "Contract" Program with Extreme Acting-Out Criminal Offenders 2 n.*, n.d. (in a portion not reprinted in $\mathrm{J}$. Katz, supra note 35 ).

${ }^{40}$ Of the 64,5 did not consent at all and 18 others volunteered reluctantly, feeling coerced to do so. Assessment, supra note 38, at 1016. 
tional disciplinary rule, he was immediately taken to a special room, placed on a table with a physician and group of nurses present, and then administered a drug called Anectine for approximately two minutes while hospital staff told him that his transgression should not be repeated and that each future transgression would result in this same drug treatment. At the end of the sixteen month experiment, these researchers concluded that the Anectine research subjects committed fewer subsequent disciplinary infractions compared to the control group, to a statistically significant degree. Thus, they concluded, this treatment program seems a promising route for further research and implementation in correctional institutions. ${ }^{41}$

What exactly did this drug, Anectine, do that led to such happy results? In the research document, the administering physician stated that there was no risk of physical harm from the drug and that there was "no pain accompanying the procedure . . ."42 The only consequence of the drug, he said, was to induce complete muscular paralysis, during the two minutes of its administration, including the complete cessation of breathing. Oxygen was administered to the inmate to assure against any physical harm, but the inmate himself was unable to breathe or move in any way. The administering physician may have considered that "no pain" accompanied the procedure, but the inmates did not like it. According to the research document, "[s]ixteen likened the experience to dying. Three of these compared it to actual experiences in the past in which they had almost drowned. The majority described it as a terrible, scary, experience . . ." 43 The physician's bland assurance that there was "no pain" echoes the gobbledygook response of Milgram's experimenter to the teacher-subjects' misgivings, that the electric shocks caused "no permanent tissue damage, so please go on." 44

I have noted the Vacaville researchers' conclusion that after two years of the experiment, the Anectine subjects followed the institutional rules more closely than the non-Anectine control group. But what have we really learned from this about future directions for correctional policy? There is no reason at all to believe that these terror induced better-behaving inmates would

4I Id. 1016-18.

${ }^{42}$ Id. 1017.

${ }^{43} I d$.

4S See text accompanying note 28 supra. 
continue their good behavior if they were released from Vacaville. In fact, extensive research data from many different sources have virtually proven that there is no reliable correlation between a person's behavior inside and out of a prison. ${ }^{45}$ Thus it was clear from the beginning of this experiment that its "success" could only prove that subjecting prisoners to extreme terror would make them behave better inside the institution-but not necessarily anywhere else.

Why then was this experiment conducted? Didn't we already know that placing prisoners inside iron maidens, or stretching them on racks, or beating them until they felt the pain and terror of imminent death, that all of these techniques improved the state of prison discipline? But then all of these techniques clearly violate the eighth amendment to the United States Constitution. If we assume that the Vacaville researchers and their administrative superiors were acting in good faith in designing this experiment, then it must be that their technological trappings blinded them from the fact that the entire project, at least for its unwilling participants, was obviously and conclusively barred by the eighth amendment. ${ }^{46}$

It would in fact be comforting to assume that these Vacaville researchers were acting only on conscious sadistic motives, since this would make the inhumanity of this experiment less threatening, easier to control, for the future. Willful sadism can be found in all prison systems but when it is discovered, it can be clearly seen as such. ${ }^{47}$ The scientific ethos, however, obscures all this, offers just that much pause for second thought, just that much plausibility for practices which we would otherwise instinctively abhor, just that much added distance between potential victims and victimizers.

As the Milgram experiments show, distance between victim and victimizer can be a crucial determinant in regulating one's

45 See lectures by Norval Morris, "The Future of Imprisonment," especially, "Prison as Coerced Cure" 22 \& "Rehabilitating the Rehabilitative Ideal" 11-12 (The Cooley Lectures, University of Michigan, 1974); Dean \& Duggan, Problems in Parole Prediction: A Historical Analysis, I5 Social Problems 450 (1968); $c f$. Gottfredson, Assessment and Prediction Methods in Crime and Delinquency, in President's CoMm'N on LAw ENForCEMENT \& Administration of Justice, Task Force Report: Juvenile Delinquency and Youth CRIME 171 (1967). But of. Kaplan \& Meyerowitz, Psychological Predictors of Postinstitutional Adjustment Among Male Drug Addicts, 20 ARCH. Gen. Psychiat. 278 (1969).

${ }^{46}$ See Mackey v. Procunier, 477 F.2d 877 (9th Cir. 1973).

${ }^{47}$ See, e.g., Holt v. Sarver, 309 F. Supp. 362 (E.D. Ark. 1970), aff'd, 442 F.2d 304 (8th Cir. 1971). 
cruelty to the other. Physical proximity was the variable in those experiments. ${ }^{48}$ But distance by conceptual categorization seems an equally salient determinant. If we can hold fast to the conviction that our potential victims are much like us, even just like us "but for the grace of God," we diminish the likelihood that we will tolerate inflictions of the worst horrors on them. The science-sounding labels of the "criminal-insane" are at war with this purpose.

\section{Applying the Burden for Benefit of the "Criminal-INSANE"}

The discussion thus far does not prove that currently applied "criminal-insane" statuses should be abolished. But the import of that discussion should shift the burden of proof on this matter to those who would hold fast to such statuses. The proponents of these statuses should identify the particular purposes served by segregating groups of the "mentally ill" from the general criminal population and demonstrate that these purposes are sufficiently important to justify the social risks created by retention of these special segregations. To put the inquiry somewhat differently, the question is whether it is better to ignore the differences between "hard core cases" of criminals with and without psychopathology, and to act instead as if all criminals were both "mad" and "bad" in some important degree. The initial arguments in favor of this course seem powerful. What can the proponents of continued categorical differentiations offer in rebuttal? To pursue this question, the discussion must now proceed category by category.

\section{A. Defendants Found Mentally Incompetent to Stand Trial}

The incompetency to stand trial doctrine presents a paradigm of the abuses and the roads to reform of the "criminal-insane" statuses. Norval Morris and I have written at some length on this, arguing that the incompetency doctrine as

${ }^{48}$ S. Milgram, supra note 24 , at $32-36$. Optimistic hopes that ensuring proximity effectively guards against human cruelties must be tempered by recalling, from the Milgram experiments, that even seated side by side, with the subject required to force the victim's hand onto the shocking metal plate, thirty percent of the subjects ignored the victim's agonized cries and proceeded on order to the highest shock levels. Id. 35 (Table 2). 
such should be abolished and that mental incompetency should no longer be a bar to criminal trial but merely one appropriate ground for authorizing time-limited trial continuances. ${ }^{49}$ During these continuances, we have proposed, the state should provide therapeutic resources (including in some cases compelled mental hospitalization) attempting to remedy the defendant's disability and make him competent for trial. But if these attempts fail (or, more precisely, if they do not succeed in a very short time), criminal trial should go forward notwithstanding. It is not necessary to repeat the full argument for this position here. Sketching the outlines of that argument, however, will indicate the way in which our proposal to abolish the incompetency doctrine stands in the broader context of the discussion here.

The central avowed purpose of the incompetency doctrine has been to assure fair treatment to criminal defendants, on the quite sensible ground that mentally incapacitated persons may be unable effectively to defend themselves. ${ }^{50}$ If, however, we compare this special dispensation for the mentally disordered criminal defendant with the treatment provided defendants with trial disabilities unrelated to psychopathology, the necessity for this "criminal-insane" status becomes suspect. A criminal defendant, for example, may be equally disabled if his crucial alibi witness fails to testify. State resources are provided to remedy this disability, in the constitutional guarantee "to have compulsory process for obtaining witnesses in [the defendant's] favor . . .."51 But if these resources are insufficient to cure the disability-if, for example, this crucial witness cannot be located within a relatively short time-the criminal trial goes forward nonetheless. ${ }^{52}$ For persisting mental incapacities, however, criminal trial is permanently barred under current doctrine.

At first glance, this special treatment of mental disability might appear more favorable to the defendant. But that is only at first glance. In virtually every state jurisdiction the criminal defendant has been indefinitely confined in a state mental institution until the lucky day when his mental incapacity was "cured" and he was finally eligible for criminal trial on the

${ }^{49}$ Burt \& Morris, $A$ Proposal for the Abolition of the Incompetency Plea, 40 U. CHI. L. REv. 66 (1972).

${ }^{50} \mathrm{Id} .75$.

${ }^{51}$ U.S. Const. amend. VI.

${ }^{52}$ United States v. Harris, 441 F.2d 1333, 1336 (10th Cir. 1971); 3 C. WRIGHT, Federal Practice and Procedure $\$ 832$, at 338 (1969, Supp. 1973). 
charge which remained outstanding. ${ }^{53}$ The practical impact of this solicitude was graphically described in a careful study of the fate of criminal defendants found incompetent to stand trial in Massachusetts. The investigators found that "more [incompetent defendants confined in the state mental institution] . . . had left . . . by dying than by all other avenues combined."54

Occasionally the plight of an individual incompetent defendant reached visibility, such as the case of Alfred von Wolfersdorf, an eighty-six-year-old man confined in New York for trial incompetency for almost twenty years. ${ }^{55}$ During his confinement, von Wolfersdorf steadfastly maintained his innocence of the charge. Habeas corpus was sought for this old man with, as Judge Frankel put it, the "poignantly modest request"56 that he be transferred from the criminally insane mental institution to a civil institution. The state attorney general refused to make this possible by dismissing the outstanding indictment, though he conceded that the death of "key witnesses ... . and the passage of time" made it "highly unlikely that the [defendant] could be brought to trial"57 even if he were miraculously made competent. Judge Frankel ordered that the defendant be transferred to the civil institution, and observed, "Cases like this could encourage the canard that $\mathrm{Mr}$. Bumble was too generous by half when he suggested that 'the law is a ass." "58

Or consider Tony Savarese, a criminal defendant in Massachusetts found, in effect, incompetent to stand trial in $1924 .{ }^{59}$ The following notation was entered in his hospital record in 1936:

$\mathrm{He}$ is oriented in all three spheres. Memory is good. No hallucinations of any kind were elicited. Claims he is entirely innocent of the crime for which he was arrested. No delusions were determined but there seems

${ }^{53}$ Burt \& Morris, supra note 49 , at $66-67$

${ }^{54}$ McGarry, supra note 15 , at 1181.

${ }^{55}$ United States $e x \mathrm{rel}$. von Wolfersdorf v. Johnston, 317 F. Supp. 66 (S.D.N.Y. 1970). For an analysis of the case by von Wolfersdorf's attorney, see B. ENNIS, Prisoners of Psychiatry 63-84 (1972).

56317 F. Supp. at 67.

57 Id.

${ }^{58} \mathrm{Id}$.

${ }^{59}$ A complete case study, consisting of substantially every entry in Tony Savarese's hospital record from 1923 to 1956, appears in J. KaTZ, J. GoldsTeIN \& A. Dershowrtz, Psychoanalysis, Psychiatry and Law 634-50 (1967). "Tony Savarese" is a fictitious name adopted by the authors to protect the defendant's privacy. 
to be a persecutory trend to his ideas. He is emotionally very unstable. Has frequent periods of excitement. Thinks that everybody is against him.... He is in good contact with his surrounding and shows fair insight but his judgment is defective. ${ }^{60}$

Mr. Savarese remained confined for thirty-four years; in 1958 he was permitted to plead nolo contendere to the still outstanding charge and was placed on two years' probation. ${ }^{61}$ This record raises some question about whose judgment was in fact defective.

It may appear that in the guise of protecting the mentally ill, the criminal justice system has merely victimized them. But this indictment may be wrong. There is frequently good reason for confining persons who have committed criminal offenses, and their mental disability does not necessarily reduce the urgency or justice of this course. Both von Wolfersdorf and Savarese had been accused of murder. Von Wolfersdorf's co-defendant, who had implicated him in a brutal kidnapping-murder of a young boy, was no longer available as a witness because the state had executed him for this offense seventeen years earlier. ${ }^{62}$ But the state, by giving special significance to these defendants' mental disabilities, was unwilling either to release them or to try them for the alleged offense and thus comfortably justify their continued confinement. The conflicting motives provoked by the spectre of mental illness-in simple outline, solicitude and fear ${ }^{63}$-appear to have induced state paralysis. No one reaps advantage from this situation-neither the defendant, obviously, nor the rest of us who, when forced to confront our actions, are ashamed and, when permitted to ignore those actions, must necessarily remain uneasily guilty.

The resolution of these conflicting motives is not to ignore one for the other, but to keep them both in balanced view. A defendant's mental incompetency should not be ignored. We should provide ample resources, as quickly as possible, to assist the defendant toward full competency. But when this result is

${ }^{60} I d .638$.

61 Id. 648.

62317 F. Supp. at 67.

${ }^{63}$ Cf. Goldstein \& Katz, Abolish the "Insanity Defense"-Why Not?, 72 Y ALE L.J. 853, 868 (1963): "[L]argely unconscious feelings of apprehension, awe, and anger toward the 'sick,' particularly if associated with 'criminality,' are hidden by the more acceptable conscious desire to protect the 'sick from criminal liability." 
not quickly achieved and clear advantage from our solicitude to the disabled defendant cannot be assured, we should then openly acknowledge our companion motive-that we fear the possible social dangerousness of this person and we want rigorously to test that issue and respond with equal solicitude for our own safety. ${ }^{64}$

The Supreme Court has recently taken the first step toward a more rational treatment of incompetent defendants. In Jackson $v$. Indiana, ${ }^{65}$ the Court invalidated an indefinite confinement "until competent" of a permanently incompetent (deaf-mute, severely retarded) defendant, and ruled that any incompetency commitment must be preceded by proof of "substantial probability" that the defendant will become competent "in the foreseeable future."66 But Jackson did not address the disposition of the criminal charges against a permanently incompetent defendant. The likely consequence of this ruling is that criminal defendants who had previously been indefinitely confined based on a trial incompetency finding alone will now be civilly committed for "mental illness" and "dangerousness to others." 67 The "criminalinsane" can thus be confined as such by yet another name.

\section{B. Civil Commitment for Danger to Others}

Civil commitment for dangerousness may serve, in some cases, as a substitute for criminal proceedings; in any case it purports to provide a "preventive detention" against criminal acts. The reform of civil commitment for danger to others is a necessary corollary to implementation of other reforms of the "criminal-insane" status that are proposed in this Article. ${ }^{68}$ Current reform efforts for civil commitment have aimed at two targets: linking the current open-ended "mental illness" standard with findings of "dangerousness to self or others" and requiring that civil commitment proceedings adopt virtually all of the procedural trappings of a criminal trial. ${ }^{69}$ But these two targets divert

64 Burt \& Morris, supra note 49 , at $79-81$.

65406 U.S. 715 (1972).

${ }^{66} I d$. at 738 .

${ }^{67}$ Burt \& Morris, supra note 49, at 70-71.

${ }^{68}$ For a discussion of these reforms, see text accompanying notes 81-85 \& 102-12 infra.

${ }^{69}$ See Lessard v. Schmidt, 349 F. Supp. 1078 (E.D. Wis. 1972), vacated, 94 S. Ct. 713 (1974); Heryford v. Parker, 396 F.2d 393 (10th Cir. 1968); Bell v. Wayne County Gen. Hosp., Civil Action No. 36384 (E.D. Mich., June 4, 1974). 
attention from the central mark: if civil commitment is to be so much like a criminal trial, both in its substance and procedure, why should there be civil commitment at all?

There is one legitimate reason for preserving civil commitment: for short term, emergency interventions to stop an apparently deranged person from inflicting unintended harm on himself or others. A person's destructive conduct toward himself or others is frequently meant, however unconsciously, as a cry for help, for constraint, for proof that others care enough to intervene. Civil commitment, properly limited, can thus be an act of true solicitude. It can be an opportunity for a mentally ill person to confront the fact of his illness, to understand that he wants to act and to be better, and to realize that others might help him toward that goal. ${ }^{70}$ But this solicitude, when linked to indeterminate confinement, is readily transformed into darker motives. "As the term of a civil commitment lengthens ... its claim to a therapeutic purpose loses all plausibility. Community protection becomes its predominant, if not exclusive, purpose, and civil commitment becomes the functional equivalent of criminal commitment."71

Preventive detention, based on some plausible indication of future dangerous conduct, is not unknown to our criminal law. Convictions for threats alone of bodily injury, for possession of firearms or burglar's tools, even for unsuccessful attempts at crime, are all well-accepted examples. ${ }^{72}$ Many criminologists are currently advocating that preventive detention be more directly practiced by resting imposition of criminal sentence explicitly on

${ }^{70}$ Jay Katz has aptly made this point:

Most persons whom society involuntarily commits are consciously and unconsciously so convinced that no one cares, indeed they look at offers of help with such suspicion, that a sustained period of exposure to an unaccustomed world of trust, respect, and care is required in order to attempt to modify these beliefs. It is possible, without precisely knowing when it is and when it is not, to change defiant, ignorant, and fearful attitudes about treatment through patient and persistent efforts in an institutional setting. Behind the conscious refusal of treatment, other unconscious wishes also operate-to be protected, to be cared for, to be sustained, to be helped. What weight should be given to these wishes when they are almost drowned out by words which damn their own self and the world?

Katz, The Right to Treatment-An Enchanting Legal Fiction?, 36 U. CHI. L. Rev. 755, 771 (1969).

${ }^{71}$ Burt \& Morris, supra note 49, at 73. See also Katz, supra note 70, at 773. 1960).

${ }^{72}$ See, e.g., Moder Penal Code $\$ 221.1$, Comment at 54-56 (Tent. Draft No. 11, 
a judgment of future dangerousness. Norval Morris, in an important lecture series recently delivered at the University of Michigan, has argued against this policy essentially on the ground that our predictive powers for dangerousness are currently seriously inadequate, that significant numbers of "false positive" predictions will always be unavoidable because of the inherent difficulty of this predictive enterprise, and that confinement of any person based solely on his categorically statistical likelihood of future dangerousness is unjust. ${ }^{73}$ In warning of the social dangers of explicit "dangerousness" confinements for convicted criminals, Morris stated:

[W]e possess an extremely convenient mechanism by which to conceal from ourselves our critical capacity as predictors-the mask of overprediction. If in doubt, put him in or keep him in. Why risk injury or death to potential innocent victims, particularly since the freedom involved is that of a person who has been convicted of a crime? . . . What is wonderfully convenient about this overprediction of risk is that the predictor does not know who in particular he needlessly holds. ${ }^{\mathbf{7 4}}$

This critique applies with even greater force to indefinite civil commitment practices. Even more than for the convicted criminal, we have multiple social and psychological mechanisms for averting our eyes from the "mentally ill." Our rationalistic model of the criminal justice system-that the criminal "could control himself" and was thus "responsible" for his action and "deserved punishment"-permits us generally to look more directly at, and speak more plainly to, convicted criminals about our anger at and fear of them. But our image of mental illness evokes rage beyond control. The intrapsychic mechanisms by which we defuse our own rages are insistently called into force by persons who vividly lack such psychic control mechanisms. By whatever means, we must put distance between "us" and "them," between "ourselves" and the part of us that they represent and that threatens our self-control. Invocation of civil commitment, with its forbidding and comforting labels of "psychoses," and its trappings of psychiatric personnel and therapeutic rhetoric,

${ }^{73}$ Morris, The Future of Imprisonment: Toward a Punitive Philosophy, 72 MICH. L. REv. 1161, 1164-73 (1974) (originally a Cooley Lecture, University of Michigan, 1974).

${ }^{74}$ Id. 1169. 
helps give us this distance. It helps "us" avert our eyes from "them" and from the consequences of our aversion to them.

There are social and personal benefits from civil commitment, but they can be assured only by exorcising the dark motives and dire consequences that attend our current uses of this power. In civil commitment practices, the mutually confusing and corrupting linked status of "criminal-insane" must be split apart. Civil commitment can be restricted to the "insane" who need "treatment" by limiting its application to short term crisis interventions. For the rest, for those who need something more and something more distasteful than "treatment," application of the criminal laws must suffice. It may be that preventive detentions based on dangerousness predictions will come into use in the general criminal justice system, but the propriety of such general use can be more clearly appraised if explicit dangerousness confinements are not imposed on the "mentally ill" as such.

In the future, identifiable psychological characteristicssome species of "mental illness" whose identification is peculiarly within psychiatric provinces-may be validated as a prime predictor of dangerousness. But that validation has not yet come; objective factors, such as age and past overt conduct, are the best current predictors, as inadequate as these are. ${ }^{75}$ If a "mental illness" label in the future becomes an adequate indicator of social danger, there will still be powerful reasons for confining the application of such predictions to persons already caught in the ordinary criminal justice system. But today, in the absence of such validated knowledge, this position, and its concomitant implication for the abolition of indeterminate civil commitment, is clearly compelling.

\section{G. The Insanity Defense}

The case for abolition of the insanity defense has been powerfully advanced in recent years. The abolitionists have put forward several basic contentions. First, in practical effect, an insanity finding is no "defense" because virtually automatic indeterminate confinement follows from it in almost every jurisdiction. ${ }^{76}$ Second, the insanity standards however formulated

${ }^{75}$ See note 17 supra. For a persuasive critique of civil commitment confinements, see Livermore, Malmquist \& Meehl, On the Justifications for Civil Commitment, 117 U. PA. L. REv. 75 (1968).

${ }^{76}$ For a brief discussion of the disposition of those acquitted by reason of insanity, see S. Brakel \& R. Rock, supra note 16, at 404-05, 430-43 (app.). 
cannot successfully distinguish among the large numbers of criminals (particularly violent criminals) suffering from significant psychopathology. Third, if it is unjust to impose stigmatizing blame on a criminal actor motivated by psychopathology beyond his conscious control, it would seem equally unjust to impose blame on an actor led to crime by sociological forcesa broken family, racial prejudice, grinding poverty and the like -equally beyond the actor's choice or control. In terms of the earlier discussion here, the case for abolition seems unanswerable-the insanity defense does not reliably work to the defendant's advantage though it is touted as an act of social solicitude, and though "hard core cases" can be distinguished, the differences between most criminals and these "criminal-insane" vanish on careful analysis. ${ }^{77}$

But these considerations do not conclude the argument. Though the defendant may not reliably benefit from availability of the insanity defense (at least since the death penalty's demise), there are reasons to believe that the insanity plea serves an important social purpose. Some evidence on this score is suggested by the enormous volume of academic attention to this issue, while ignoring the conjunction of the police and mental health powers with greater practical significance. ${ }^{78}$ This scholarly obsession may, of course, be merely symptomatic of general academic psychopathology. But this obsession suggests something more to me-that the ethical and psychological issues vividly raised by the insanity plea are central to this society's view of the function of its criminal justice system.

Judge Bazelon wrote in Durham, " Our collective conscience does not allow punishment where it cannot impose blame." "79

77 For elaboration of these arguments, see Morris, supra note 16; id. 544-47 (appendix summarizing the other major insanity defense abolitionist views in the current literature).

${ }^{78}$ In 1967, for example, a national survey of state mental institutions revealed that of some 11,000 persons involved in the criminal justice system in such institutions, only 409 , or four percent, had been found not guilty by insanity. Slightly more than half of these 11,000 were involved in trial incompetency adjudications and the rest were convicted criminals transferred from prisons for "mental illness." P. Scheidemandel \& C. KanNo, The Mentally Ill Offender 20 (1969). See also Morris, supra note 16, at 519:

Overwhelmingly, criminal matters are disposed of by pleas of guilty and by bench trials. Only the exceptional case goes to trial by jury. And of these exceptional cases, in only two of every hundred is this [insanity] defense raised. Does anyone believe that this percentage measures the actual significance of gross psychopathology to crime?

${ }_{79}$ Durham v. United States, 214 F.2d 862, 876 (D.C. Cir. 1954) (quoting Holloway v. United States, 148 F.2d 665, 666-67 (D.C. Cir. 1945)). 
The British Royal Commission on Capital Punishment stated, "Views have changed and opinions have differed . . . about the standards [for insanity] to be applied . . . but the principle has been accepted without question." ${ }^{80}$ That is no reason to continue unquestioning acceptance. But still, it is an important fact that the insanity defense has been much explored, its continued existence has recently been much debated, and yet its power to transfix our imaginations seems unabated. Unlike the other "criminal-insane" statuses discussed here, the insanity defense takes place at the center of the ritual of the criminal trial. It alone purports to bring into focus the grand issues of moral responsibility underlying the imposition of criminal norms and punishments. The continued existence of the defense, at least in its ritual aspects, may be central to preserving the ethical integrity of the criminal justice system, perhaps only in a popular sense or perhaps in more than that.

This conclusion is difficult to prove and even more difficult to evaluate. And if the earlier argument here is accepted, that the burden of proof rests on those who would retain the existing "criminal-insane" rubrics, this Delphic justification for the insanity defense might not seem adequate to the task. Indeed, it might be argued from this that abolition of the insanity defense is the most important step toward achieving the goal proclaimed in the preceding section of this Article-that the public should be frontally forced to acknowledge that Science has no special claim to custody or cure of any predesignated subgroup within the criminal population ... but maybe not.

For the trial incompetency and civil commitment statuses, I have argued the importance of preserving the solicitude provided to the mentally disabled while restricting the impact of those statuses to guard against their excesses. Perhaps for the insanity defense it is equally possible to preserve the solace it offers for mental disabilities-including the disability afflicting those people who cling to the notion that "insane people" must not be held "responsible" for "criminal acts"-while combatting the harm worked by the doctrine's operation. The only aspect of the insanity defense that appears worth preserving is its courtroom ritualization. Retaining the ritual for its own sake might be justified by the same reasoning that occasionally moves agnos-

${ }^{80}$ Royal Commission on Capital Punishment, 1949-53 Report, CMD. No. 8932, at 98 (1953). 
tics to attend religious services: to acknowledge strong attachments to the past and to hedge bets for the future. But giving any dispositive effect to an insanity ruling, outside the trial drama, creates excessive risks of social harm.

The first small step toward this goal would be to eliminate indeterminate commitment as a response to a criminal insanity finding. The premise of such commitment, whether prescribed by statute as a consequence of this finding, as in many jurisdictions, or accomplished by invoking ordinary civil commitment procedures after such finding, is that these "criminal-insane" must be confined until "cured," unlike other convicted criminals for whom fixed terms are set and who are released whether or not "cured" of criminality. ${ }^{81}$ Since it cannot be demonstrated that recidivism is more likely for the criminally insane than for others who have committed criminal acts, there is no adequate reason to protect society more rigorously from one group than from the other. Accordingly, whatever maximum prison term society has chosen for a given criminal act should limit both groups' confinement equally.

But imposing the same maximum term gives insufficient assurance of equal treatment to those found not guilty by insanity. They are still likely to suffer from adverse discrimination in parole availability, in objective conditions of confinement, and in social stigma both during and after confinement. Short of abolishing the criminal insanity defense, there is no way conclusively to assure against these discriminations. It seems possible, however, that these adverse effects follow not so much from the criminally insane status as such but rather from the fact of separate institutionalization attaching to that status. Though this cannot be clearly proven, it must at least be questioned whether separate institutionalization for these persons serves any important purpose. If none can be identified, that would seem reason enough to act on the likelihood that the visibility attached to separate institutionalization would foster any potential for adverse discrimination against the criminally insane.

Separate institutions for the criminally insane have been considered necessary to assure a "medical-custodial disposition" rather than a "punitive-correctional disposition" for them. ${ }^{82} \mathrm{But}$ in practice this solicitude has clearly proven fictitious. John Doe's

${ }^{81}$ See, e.g., Ragsdale v. Overholser, 281 F.2d 943 (D.C. Cir. 1960).

${ }^{82} C f$. Model Penal Code $\S 4.01$, Comment (Tent. Draft No. 4, 1955). 
testimony, cited earlier, ${ }^{83}$ that special state institutions for the "criminal-insane" statuses are "just nothing but for detention and to get rid of [them] and, well, a place to stay," generally holds true. Occasionally state mental institutions convincingly present aspects of medical-custodial dispositions. But state prisons exhibit those same elements at least as frequently. There is, in short, nothing in a well-run prison system that bars provision of therapeutic services fully equalling whatever might be provided in specially identified institutions for the "criminal-insane." It is, of course, difficult to maintain a supportive, therapeutic milieu while continually assuring that patients cannot escape, but prisons and maximum security mental institutions share this problem equally.

This is not merely a jurisdictional proposition, an argument that special institutions should be conducted under the aegis of the state corrections department rather than the mental health department. It is an argument instead against any clearly identifiable special institution for long term confinements. The projected organization of psychiatric services in the federal prison system is the model intended here. ${ }^{84}$ Basic psychiatric care should be provided to prisoners who remain in the regular prison population. Separate psychiatric facilities for prisoners should be available only for short term response to acute psychotic episodes, providing stabilizing therapies designed to permit rapid return to the general population where psycho- and chemotherapeutic support could be continued.

Some psychotic prisoners may be so unrestrainedly violent that separate confinement for long terms is necessary for them. But all difficult-to-control violent prisoners present the same confinement problems. On this score, there might be justification for special institutions to hold prisoners who are particularly violent actors in the prison system. Prison violence is no justification, however, for special institutions to hold "mentally ill" violent prisoners.

The projected federal model suggests that the abolition of special long term psychiatric confinement institutions is therapeutically feasible. The multiple adverse consequences that fall

83 Note 21 supra.

${ }^{84}$ See Hearings on Behavior Modification Programs, Federal Bureau of Prisons, Before the Subcomm. on Courts, Citil Liberties, and the Administration of Justice of the House Comm. on the Judiciary, 93d Cong., 2d Sess. 46-48 (1974). 
on the "criminal-insane" from their highly visible separate institutionalization demonstrates the imperative justice of this proposal. It may seem odd to propose retention of the criminal insanity defense so long as no practical consequences follow successful invocation of that defense. But if the sole justification of the criminal insanity plea is its ritual function, it should be cleanly limited to ritual. By this proposal the "criminal-insane" label would adhere to some prisoners. But common sense and recent empirical research suggest that the predominant ethos of the institution would obscure the special labels on a few inmates, and that institutional staff who are forced to treat these special status inmates as no different from others would quickly come to see them as no different in fact. ${ }^{85}$

The social dangers of targeting a group of prisoners, specially decked in the trappings of Science, were discussed earlier. ${ }^{86}$ On this score, retaining the insanity defense is a tolerable social policy only if those labelled insane in a criminal trial disappear quickly and completely from public view, as such, following the trial. When the behavioral scientists might later pursue these targets-as the Detroit psychosurgeon hunted out the "criminal sexual psychopaths" alone in the Michigan institution-they might be found through record entries, but institutional staff would be hard put to provide testimonials that they were radically different from others.

\section{D. "Criminal Sexual Psychopathy," "Defective Delinquency," and the Like}

The case for retaining the insanity defense has been made only half-heartedly. But no one can have heart for retaining the other crude depictions of "criminal-insane" statuses created by relatively more recent legislation, such as "criminal sexual

8s Henry Steadman and Joseph Cocozza have traced the institutional careers of a group of "criminal-insane" status convicted criminals who were kept beyond their maximum prison sentences in a special institution, most of them for decades, based on psychiatric estimates of their "mental illness" and "dangerousness." These prisoners were forced into general civil institutions by the Supreme Court's decision in Baxstrom v. Herold, 383 U.S. 107 (1966), and although staff there expressed great initial fear, these inmates were easily assimilated into the civil population. A majority of these transferred inmates were quickly and successfully released to the community. H. STEADMAN \& J. Cocozza, supra note 15, ch. 6 . For suggestion of the proposition that the institutional setting dictates staff perception of patients' mental health more than patients' individual characteristics, see Rosenhan, On Being Sane in Insane Places, 179 ScIENCE 250 (1973).

${ }^{86}$ Text accompanying notes $18-48$ supra. 
psychopaths" or "defective delinquents."87 These special depictions, which exist in the statutes of some twenty-eight jurisdictions, are avowedly hybrids - conceptually different both from the "pure insanity defense" and from "pure criminality." 88 Both conceptually and practically, these depictions are best characterized as pure obscenities, at least in the sense that they are utterly without redeeming social value.

The mutual corruptions of therapeutic and community safety motives are sharply etched by these statutes. Under them, courts are permitted to impose indeterminate confinement terms no matter what maximum term the criminal offense charged might carry. The applicability of these statutes are so vaguely open-ended that almost any "socially undesirable" person can be reached. Consider, for example, the reach of the Maryland act's definition of a "defective delinquent":

[A]n individual who, by the demonstration of persistent aggravated anti-social or criminal behavior, evidences a propensity toward criminal activity and who is found to have either such intellectual deficiency or emotional unbalance, or both, as to clearly demonstrate an actual danger to society so as to require . . confinement and treatment . . . ${ }^{89}$

The link between "danger" and "require[d] . . . confinement and treatment," triggered by an utterly plastic conception of "intellectual deficiency or emotional unbalance," is rarely so blatant in these statutes, but this is always the underlying architecture of them.

Implementation of the Maryland statute illustrates a further problem with these "criminal-insane" statuses, considered earlier: the dangers of special institutionalization. Persons caught in the "defective delinquency" net in Maryland are sent to a special institution for "defective delinquents" at Patuxent. The avowed intent for the creation of this institution was to concentrate treatment resources in one place for this group that might uniquely benefit from those resources. In practice, Patuxent has been more successful in attracting funds and credentialled personnel

87 The case for abolition of these special statuses has been compellingly drawn in $\mathrm{S}$. BRAKEL \& R. Rock, supra note 16, at 341-75.

${ }^{88}$ Id. 341-43.

${ }^{89}$ Md. AnN. Code, art. $31 \mathrm{~B}, \S 5$ (1971) (emphasis added). 
than most state institutions designed to serve the "criminalinsane" statuses. ${ }^{90}$ But this very success has created special problems for its inmates. The expenditures per capita at Patuxent are markedly higher than in ordinary correctional institutions, and there is enormous consequent pressure-rising to crescendoes annually before the legislative appropriations committees-to justify this special expenditure.

The Patuxent administrators must claim much more "success" than ordinary prison administrators and those claims have been grandiosely paraded. Patuxent has put forward claims that-unique among correctional institutions in Maryland and, indeed, in the world-persons who have completed their correctional-therapeutic regime have had only an eight percent rate of recidivism.91 Patuxent apparently achieved this happy result by releasing almost no one. This does not mean that these few alone are released from Patuxent, but rather that the inmates have maintained a constant flurry of litigation so that in practice state and federal judges have offered the principal route out of the institution. With their more troublesome inmates thus taken from them, the Patuxent scientists have ungenerously touted their own rehabilitative successes in comparison to the subsequent recidivist careers of the judicially released inmates. ${ }^{92}$

One large embarrassment does, however, shine through the glowing reports of success at Patuxent. Though those who have completed their therapeutic program are purportedly more law-abiding than others, the published data nowhere describe the detailed content of that program. If Patuxent alone has found the correctional therapist's long-sought alchemy that turns mad dogs into lambs, it is at least churlish of the institution to withhold that potion from the rest of us. The chief psychologist

${ }^{90}$ See Director of Patuxent Institution v. Daniels, 243 Md. 16, 53, 60-61, 221 A.2d 397, 419-23, cert. denied, 385 U.S. 940 (1966) (upholding the constitutionality of Patuxent's statute and operations).

${ }^{91}$ See id. at 63, 221 A.2d at 425 (app. A).

92 According to the Patuxent claims, id., in the first ten years of its operations, only 155 (or $27 \%$ ) of its 581 committed inmates were released. Of this 155 , only 26 (or $4.5 \%$ of all committed inmates) were released at the recommendation of Patuxent staff; of those, only two (or 8\%) were subsequently apprehended for "violations." Of the other 129 inmates, released by the courts without Patuxent recommendations, 62 (or 48\%) were subsequent "violators." These statistics give no indication of any differences between the court- and institution-released inmates-for example, length of confinement, age at release, seriousness of original offense or subsequent "violation." Further, the accuracy of these statistics is called into question in Schreiber, Indeterminate Therapeutic Incarceration of Dangerous Criminals, 56 VA. L. REv. 602, 619, 627 (1970). 
at Patuxent has publicly described the content of the therapeutic program as "eclectic," dependent on different treatment strategies pursued by separate "teams" within the institution. ${ }^{93}$ The program, that is, is the classically inscrutable black box from which nonviolence is purported to emerge. These claims would be merely silly if the prolonged confinement of persons did not result from them and if Patuxent's touted success did not tempt other states to emulate its "program."

Patuxent, and the Maryland defective delinquency statute, provide an additional illustration of the urgent need to insulate the criminal justice system from scientific hucksterism, and to free prisoners from formal labels and institutions that provoke the grandiosity of the old and new behavioral technologists.

\section{E. Prisoners Found "Mentally Ill"}

It may seem odd that special mention must be made of the disposition of convicted criminals who, during their prison term, are found "mentally ill." But ironies abound in the formalistic category- and institution-ridden way this society responds to the "criminal-insane." In a world of common sense,

it would appear that the problem of mental disability developed or detected in prison is one of the prisoner's trying to assert his disability and obtain transfer to a treatment-oriented institution. As it turns out, however, the thrust of the problem is usually the reverse: it is the prison authorities who seek to effectuate a transfer, and the prisoner who resists it. ${ }^{94}$

This is testimony again that our benevolence toward the "criminal-insane" masks other motives, most starkly visible to the objects of our care.

Here, as in the other "criminal-insane" statuses discussed, the solution seems clear. Various forms of well-accepted psychotherapies should be provided to mentally ill prisoners in ways that do not demarcate them dramatically apart from other prisoners. This solution runs counter to a long reformist tradition

${ }^{93}$ Statement by Dr. Arthur Kandel at a conference sponsored by the Hastings Institute for Society, Ethics and the Life Sciences, New York City, Dec. 8, 1973. For a discussion by the director of Patuxent and several associates, see Boslow, Rosenthal \& Gliedman, The Maryland Defective Delinquency Law: Psychiatric Implications for the Treatment of Antisocial Disorders under the Law, 10 BRIT. J. DelinquenCY 5 (1959).

${ }^{94}$ S. Brakel \& R. Rock, supra note 16 , at 407. 
insisting that only "hospitals" and not "prisons" could offer help to the mentally ill. But "hospitals" for the criminally insane have not met this prescription. Further, it would solve nothing to confine mentally ill prisoners in civil mental hospitals with the hope that they would be treated indistinguishably from all patients. In general civil hospitals, mentally ill prisoners would suffer the same fate that has afflicted persons committed to civil hospitals for trial incompetency with outstanding criminal indictments. ${ }^{95}$ Because of their peculiar involvement with the criminal justice system, the hospital authorities would be sensitive to public fear of these patients in particular and, among other adverse effects, would see special need to ensure against their escape and to hold them for long terms. ${ }^{96}$ Mentally ill prisoners can be protected from seriously adverse discriminations only by keeping in high visibility the proposition that they are not very much different from all prisoners.

\section{The Burden on the Courts}

It may be that these proposed reformations of the "criminal-insane" statuses would not have much practical impact. Our social commitment to special handling of people with "dangerous mental illnesses" may be so deep-rooted that other guises will be found for this purpose. The pressures for using novel biotechnologies for social control may be so compelling that purging the temptations offered by the science-sounding labels of the "criminal-insane" will provide only momentary diversion before the technologists find new targets inside correctional institutions. But the magnitude of the current wrongs and the future social harms that appear linked to these reified "criminal-insane" statuses are sufficient to call into doubt the case for their continued existence, and the arguments for retaining these statuses intact are not strong enough to overcome this doubt. Once the burden of proof has been placed on justifying the current existence of these statuses, the burden cannot be adequately discharged.

But what, then, is the proper role of the courts in all this? The future directions of the "criminal-insane" statuses have been

${ }^{95}$ See text accompanying notes 49.67 supra.

96 If long term civil commitment is abolished, as proposed in text accompanying notes 68-75 supra, the special status and "dangerousness" of these prisoners would be even more starkly apparent. 
discussed thus far apparently at large, as matters of social policy. But the normative proposition underlying all of this discussion is quite familiar to the courts: it is the norm of equal protection of the laws. In each of the "criminal-insane" statuses, our law currently designates a group from among the criminal population for different treatment. The question for equal protection analysis is whether the differences between these designated groups are sufficient to warrant the differential consequences following from that categorization.

In view of the seriously adverse consequences, both to the individuals labeled and to society generally, of the "criminalinsane" statuses, a court could justifiably invalidate them for the reasons and in the manner proposed in the preceding discussion. I am not here necessarily suggesting that "criminal-insane" is a suspect categorization. I am suggesting that equal protection analysis generally demands some greater persuasiveness for legislative categorization if significant adverse individual and social consequences attach to that categorization. ${ }^{97}$ On this score, the "criminal-insane" statuses cannot pass muster.

The Supreme Court has already pointed in this direction in its few considerations of the "criminal-insane" statuses. In Baxstrom $v$. Herold,,$^{98}$ the Court invalidated on equal protection grounds a statute providing that prisoners found "mentally ill" could be confined in an institution for the criminally insane at the end of their prison term. This statute employed substantive standards and procedures less rigorous than those required for ordinary civil commitments. The Court's result was relatively easy to reach because there seems little reason to treat a mentally ill former prisoner different from any other mentally ill person. There are some arguable differences-for example, prisoners even at the end of their terms might generally be presumed more "dangerous" than others-but the Court gave short shrift to the possible differences. ${ }^{99}$

More recently the Court has scrutinized aspects of other "criminal-insane" statuses, in one case invalidating indeterminate

${ }^{97}$ See Reed v. Reed, 404 U.S. 71, 75-76 (1971); Gunther, The Supreme Court, 1971 Term-Forward: In Search of Evolving Doctrine on a Changing Court: A Model for a Newer Equal Protection, 86 Harv. L. Rev. 1, 20-24 (1972). See generally Developments in the Law-Equal Protection, 82 HARv. L. Rev. 1065 (1969).

98383 U.S. 107 (1966).

${ }^{99}$ Id. at $114-15$. 
commitment based solely on trial incompetency ${ }^{\mathbf{1 0 0}}$ and in two other cases calling into question statutes which converted fixed term prison sentences into indeterminate commitments based on "sex deviancy" or "defective delinquency" mental illness labellings. ${ }^{101}$ In all of these cases, as in Baxstrom, the Court ruled that equal protection required application of ordinary civil commitment standards and procedures to justify special state power on grounds of mental illness.

The Court of Appeals for the Second Circuit characterized the theme of these cases in this way: "[W]e cannot tolerate two classes of insane persons-criminal and non-criminal-when we are asked to examine commitment procedures available to both." ${ }^{02}$ But insisting on comparability between the "criminalinsane" and the "noncriminal-insane" is neither a necessary nor a helpful way to apply equal protection analysis. There is in fact one adequate difference between these two groups. One group has committed criminal offenses, the other has not. Different quanta of state power over each group should justifiably follow from that difference.

The absence of any criminal conviction for the "noncriminal-insane" is the central reason, as a matter of constitutional law, for invalidating long term or indeterminate civil commitment of the "dangerous mentally ill." The criminal law, hedged round with elaborate constitutional protections, should be the basic mechanism for community protection. For the reasons discussed earlier, it is unfair and socially dangerous to proliferate other community protection mechanisms based solely on the "mental illness" of the "dangerous person" unless those mech-

${ }^{100} \mathrm{Jackson}$ v. Indiana, 406 U.S. $\overline{7} 15$ (1972).

101 In Humphrey v. Cady, 405 U.S. 504 (1972), the maximum sentence for petitioner's crime had expired and he was confined under the Wisconsin Sex Crimes Act "for a potentially indefinite period of time," $i d$. at 506. The lower court had dismissed petitioner's equal protection claim without a hearing, and the Supreme Court remanded, virtually directing that the statute be overturned. In McNeil v. Director, Patuxent Institution, 407 U.S. 245 (1972), petitioner's criminal sentence had also expired but he was confined at Patuxent for assessment as a possible "defective delinquent" under the state statute. See text accompanying notes 87-93 supra. Apparently in order to forestall the doctors from converting his fixed term sentence into indeterminate commitment, petitioner had simply refused to talk to the staff at Patuxent. Undaunted, the state contended that petitioner "may be confined indefinitely until he cooperates and the institution has succeeded in making its evaluation." 407 U.S. at 246. The Court resolved this mad standoff by invalidating petitioner's confinement.

${ }^{102}$ United States ex rel. Schuster v. Herold, 410 F.2d 1071, 1081 (2d Cir.), cert. denied, 396 U.S. 847 (1969). 
anisms are sharply and reliably different in purpose and effect from the criminal law. ${ }^{103}$ Imposing prolonged involuntary incarceration on "mentally ill, dangerous" people is not different enough from the purposes and effect of the criminal law.

To claim, as a matter of equal protection, that the "criminal-insane" and the "noncriminal-insane" must be given similar treatment obscures this important proposition. In fact, several courts have been misled by this equal protection analysis into holding that persons found not guilty by insanity can be confined only under generally applicable state civil commitment laws. ${ }^{104}$ These holdings are consistent with the internal logic of the insanity defense-that "mental illness" transforms and exculpates "criminal acts." Requiring that these defendants be confined, if at all, through civil commitment modalities is not an illogical application of equal protection analysis. But these holdings illustrate the intrinsic illogic of the insanity defense itself in its pretense that ordinary community protective purposes of the criminal law have no easily justifiable application to "mentally ill criminals." In fact, no defendant should plead or be found not guilty by insanity unless he has committed a serious antisecial act. Extended confinement of such defendants in many cases is clearly appropriate for community protective purposes. But insisting that such defendants are no different from any civilly committable person creates a powerful, though erroneous, argument for retaining the possibility of prolonged confinement for everyone subject to civil commitment. "If equal protection analysis requires equal treatment for the 'insane' and the 'criminally insane,' then states may well be drawn to greater abuse of the mad in order to be sure of ensnaring the bad."105 These holdings obstruct the centrally important goal of abolishing long term or indefinite civil commitment.

The Court of Appeals for the Second Circuit has applied this same unhelpful equal protection analysis to require application of ordinary civil commitment laws to prisoners found "mentally ill" while serving criminal sentences and transferred to state

${ }^{103}$ See text accompanying notes 68-75 supra; compare Kennedy v. Mendoza-Martinez, 372 U.S. 144 (1963).

${ }^{104}$ Bolton v. Harris, 395 F.2d 642 (D.C. Cir. 1968); People v. Lally, 19 N.Y.2d 27, 224 N.E.2d 87, 277 N.Y.S.2d 654 (1966).

105 Burt \& Morris, supra note 49 , at 70 . 
mental institutions. ${ }^{106}$ The court stated ample grounds for concern about the adverse impact of transfer from prison to mental institution:

[Transfer $n$ ]ot only . . . effectively eliminate[d] the possibility of [the prisoner's] parole, but it significantly increased the restraints upon him, exposed him to extraordinary hardships, and caused him to suffer indignities, frustrations and dangers, both physical and psychological, he would not be required to endure in a typical prison setting. ${ }^{107}$

But the remedy chosen by that court-application of openended ordinary civil commitment laws as the prelude to transfer-is not at all responsive to this problem. This court in effect said, "Special procedures are necessary to justify heaping these adverse consequences on any criminal who is found insane." Why is there any justification in making life so much more difficult for any criminal simply because he is found insane? The court should rather have ruled out the possibility of this transfer, of this stigmatizing separation in the service of Science. The Second Circuit should not have sought equality between the "criminal-insane" and "noncriminal insane." It should have insisted on equal treatment of the criminal and the "criminalinsane."

The Supreme Court cases in this area do not necessarily force equal protection analysis into this misleading mold. Baxstrom and its successor cases in the Court, ${ }^{108}$ with one exception, deal with the fate of convicted criminals confined for "mental illness" beyond the term of their criminal sentences. In these cases the Court, in effect, ruled that state power to confine these persons had ended and, if they were to be confined further, the justification must be found in laws governing all free persons -either civil commitment or a new criminal charge. It is not helpful to analyze these cases as requiring equal treatment between a group of "criminals" and others. There were no "criminals" involved in these cases, only former criminals whose sentences had expired. The Court in effect held that a person's

${ }^{106}$ United States ex rel. Schuster v. Herold, 410 F.2d 1071 (2d Cir.), cert. denied, 396 U.S. 847 (1969).

${ }^{107}$ Id. at 1078.

${ }^{108}$ See notes 100 \& 101 supra. 
prior criminality was not an adequate reason for giving the state incremental authority to confine him for "mental illness."109

The most important post-Baxstrom case did not deal with former criminals. Jackson $v$. Indian ${ }^{110}$ considered the permissible reach of state power over persons accused of criminal conduct and found incompetent to stand trial. Jackson, even more than its predecessor cases, leads toward rejection of state powers based specially on a conjunction of criminal law involvement and mental disability. For incompetent defendants, the Court authorized only short term confinement needed to assure that the defendant might go to trial. This special power over a mentally disabled defendant closely resembles traditional state power to confine criminal defendants generally-that is, power to deny bail, or set highly restrictive bail, to assure the defendant's trial availability. ${ }^{111}$ But beyond short term confinement, the Jackson Court ruled that confinement based on mental illness alone could be justified only through civil commitment proceedings. ${ }^{112}$ The Court concluded that the incompetent defendant could not be subjected to prolonged confinement based on the outstanding charge. The Court in effect held that the criminal law permits such confinement only after trial and conviction.

Jackson thus implicitly holds that a mentally ill defendant can be confined only for the same reasons that the state holds either all criminal defendants or all mentally ill persons. The Court excluded any incremental state authority based on the conjunction of "criminality" and "mental illness" presented by mentally incompetent defendants. Jackson asked not only, why should this suspected criminal be treated differently from any other mentally ill person? Jackson also asked, why should this suspected criminal be treated any differently from any other such suspect simply because of his mental illness? This kind of equal protec-

${ }^{109}$ In Humphrey v. Cady, 405 U.S. 504 (1972), for example, the Court's equal protection analysis required that if a state wants to commit all "peeping toms" to potentrally indefinite incarceration, it may directly and generally mandate such incarceration as a possible punishment for that offense. The state cannot, however, provide that the of fense shall be punishable by a one year maximum incarceration term except that any such offender who suffers from "mental ... deficiency, disorder or abnormality" shall be subject to indefinite incarceration beyond that term. 405 U.S. at 506-07. This disadvantageous conjunction of "criminality" with "mental illness" was precisely the flaw of the Wisconsin Sex Crimes Act.

${ }^{110} 406$ U.S. 715 (1972).

${ }^{11}$ See Stack v. Boyle, 342 U.S. 1 (1951).

112406 U.S. at 730. 
tion analysis-requiring clear justification of different treatment based on mental illness among those subject to criminal law -undercuts the continued existence of all of the special "criminal-insane" statuses discussed here.

This equal protection analysis does not sit sympathetically with those cases positing a constitutional "right to treatment" for persons caught in the "criminal-insane" statuses. ${ }^{113}$ There are, of course, considerable practical obstacles that encumber judicial efforts to ensure that state resources will match the therapeutic promises held out by those statuses. ${ }^{114}$ But the central obstacle is in the promise itself, in the very existence of these statuses. ${ }^{115}$ The future task for judicial intervention is not to ensure that the therapeutic promise is kept. It is rather to ensure that this society no longer holds out the chimerical and socially dangerous promises offered by the "criminal-insane" statuses.

Judge Bazelon warned of the "perils of wizardry" in his recent address to the American Psychiatric Association. He invoked the story of $\mathrm{Oz}$ to make this cautionary point:

Dorothy and her companions were none the worse for having discovered at the end of the yellow brick road that the "wizard had no magic." In fact, they gained strength once reliance on the wizard was at an end. But what if the scenario were changed? What if the wizard really possessed wizardry-his trunk now laden with bio-behavioral therapies? How would he use these skills? I can conjure up one version for you! The lion could be lobotomized; the tinman could be tranquilized

${ }^{113}$ E.g., Rouse v. Cameron, 373 F.2d 451 (D.C. Cir. 1966); Nason v. Superintendent of Bridgewater State Hosp., 353 Mass. 604, 233 N.E.2d 908 (1968).

${ }^{114}$ See Bazelon, Implementing the Right to Treatment, 36 U. CHI. L. Rev. 742 (1969); Halpern, A Practicing Lawyer Views the Right to Treatment, 57 Geo. L.J. 782 (1969).

115 Judicial "rights to treatment" have recently been bestowed on other objects of this society's ambivalent concern-mentally retarded children (Wyatt v. Stickney, 344 F. Supp. 373, 387 (M.D. Ala. 1972)) and "juvenile delinquents" (Martarella v. Kelley, 349 F. Supp. 575 (S.D.N.Y. 1972)). As with the "criminal-insane," there is considerable danger that this judicial posture will only validate the worst aspect of our treatment of these children: long term, socially isolated institutionalization. See Burt, Beyond the Right to Treatment: Strategies for Judicial Action to Aid the Retarded, in The Mentally Disabled Citizen AND the Law (M. Kindred ed. forthcoming). Compare the fate of the "treatment rights" sought by litigation at Patuxent, the Maryland "defective delinquents" institution, which has led-thus far, at least-only to general judicial validation of practices there. Sas v. Maryland, 334 F.2d 506 (4th Cir. 1964); Director of Patuxent Institution v. Daniels, 243 Md. 16, 221 A.2d 397, cert. denied, 385 U.S 940 (1966); Tippett v. Maryland, 436 F.2d 1153 (4th Cir. 1971), cert. dismissed sub nom. Murel v. Baltimore City Crim. Ct., 407 U.S. 355 (1972). See text accompanying notes 87-93 supra. 
and the scarecrow could be "therapized" with operant conditioning. All would be done by the wizard in the service of Emerald City. The cure in this situation may well be worse than the "disease!" Should the admonition be: "Fear-not follow-the yellow brick road?"116

If these perils lie ahead at the end of this road, we should think again about the path already traversed. Judge Bazelon has more than any other jurist walked this road with his eyes open. What he has seen, and what he tells us, should now lead us to retrace our steps.

116 "Wizardry," supra note 4, at 19. 